and far more than a woman of her age should have attempted; but she would not and, indeed, could not ease up ; there is no respite for a farmer in war-time. In the last year, when her head man was away ill for months, she still managed to carry on. It wore her out. She had served her generation in so many ways to the utmost of her powers, that when illness struck her, she was left with too little strength to fight for herself.

So this great-hearted woman became a war casualty, laying down her life for her country in the Battle of the Home Front.

G. L. Elles.

\section{Prof. Jan Florian}

IT is with feelings of deep regret that we have to record the death at the hands of the Gestapo of the distinguished Czech embryologist, Prof. Jan Florian, dean of the Medical Faculty in the Masaryk University, Brno, on May 7, 1942. By his researches on early human embryos, Prof. Florian had established for himself an international reputation as an embryologist and had made many friends among the anatomists in England and other allied countries.

The following notice is contributed by his teacher and friend, Prof. F. K. Studnička, of the Charles University, Prague.

During the first year of their occupation of Bohemia and Moravia, the Germans closed all the universities and colleges, seven in number, and subjected their staffs to the harshest treatment. Many of them were sent to concentration camps and died there; others were executed. The Masaryk University at Brno was especially brutally treated. The institutes were looted and some twenty members of the staff were murdered, among them Jan Florian.

Florian was born in Brno in 1897. He served as a conscript in the Austrian Army throughout the First World War, and in 1919, when the Masaryk University was founded, he was among its first medical students. In 1923 he graduated M.D. and became assistant in the Institute of Histology and Embryology. In 1928, he was admitted Docent, and in 1933 was appointed. professor of histology and embryology in the Comenius University, Bratislava. Eventually he returned to Brno as professor in succession to me.

Early in his career, Florian became interested in embryology, and with the help of Dr. O. Bittmann succeeded in forming a fine collection of wellpreserved human developmental material. He de. voted himself to the study of the early stages in his collection and, in papers published between 1927 and 1930, added much to our knowledge of early human development. We need only mention here his work on embryos Bi I (1927) and TF (1928) and his redescriptions of the Fetzer embryo, with Fetzer (1930), and the Beneke embryo, with Beneke $(1930-31)$.

In the years succeeding 1930, Florian, with the aid of grants from the Rockefeller Foundation, was enabled to spend several long periods of study-leave at University College, London, where as honorary research assistant he continued his investigations. $\mathrm{He}$ participated actively in the meetings of the Anatomical Society and contributed several valuable papers to its Journal, and he also collaborated with Prof. J. P. Hill in the description of an early human embryo (1931) and in a study of early embryonic stages of Tarsius. $\mathrm{He}$ was co-author, with Prof. Frankenberger, of a text-book of embryology, the first to be published in the Czech language, and author of a popular work entitled "From Protozoon to Man" (also in Czech).

Florian was an excellent mathematician, and utilizing the principles of projective geometry, he perfected a method of graphic reconstruction which has proved of great value in the interpretation of serial sections of embryos in which the sectional plane is oblique to the median plane of the embryo. $\mathrm{He}$ also designed an improved type of micro-manipulator.

In 1938, Florian was elected a member of the Institut International d'Embryologie, an honour he greatly appreciated. In 1939, he was appointed dean of the Medical Faculty in the Masaryk University, but he had barely assumed the duties of the office when, in November of that year, the universities were closed by the Nazis. Florian for a while tried to carry on with his work, and at the same time was active in alleviating the hardships of the families of those who had been persecuted. Eventually in October 1941 he himself was imprisoned by the Gestapo, at first in Brno, but at the end of January 1942 he was deported to the notorious concentration camp of Mauthausen, near Linz. There he was kept in solitary confinement, tortured and finally shot on May 7, along with seventy-six other prisoners.

Such was the end of an ardent and noble-hearted patriot and a gifted man of science. His death at the early age of forty-five is an irreparable loss to his beloved country and to the science he did so much to advance. F. K. STUUNičKa.

\section{Mr. J. H. Driberg}

THE death of Mr. Jack Herbert Driberg on February 5 will come as a shock to his many friends and admirers. Born in April 1888, he was educated at Lancing College and Hertford College, Oxford, and in 1912 joined the Uganda Administration, spending nine years in it before he was transferred to the Sudan Political Service, from which he was invalided on pension in 1925. In 1923 he had written his wellknown book, "The Lango: A Nilotic Tribe of Uganda", and thus established his claim as an anthropologist, and, after a training in the London School of Economics, was appointed to a lectureship in the School of Archæology and Anthropology in Cambridge. He held this post until the outbreak of the War in 1939, when he resigned and volunteered for war-work and was posted to the Near East ; at the time of his death he was concerned with Middle East affairs in the Ministry of Information.

Driberg was a man of exceptional ability, and on the sound foundation of Greats at Oxford, developed a keen sense of the right word and turn of phrase which made his "People of the Small Arrow" (1930) and "Ngato, the Lion Cub" (1933), to mention only two of his works, such delightful reading. As a teacher he was inspiring, and devoted much time to helping his students. His appreciation of the value of anthropology to administrators in the Colonial Service, gained by his experience in Uganda and the Sudan, did much to inspire Colonial probationers who attended his lectures and talked with him in his rooms with the practical value of the science in relation to their future work, and seeds were sown in successive generations of probationers which to-day are bearing fruit.

He was a good linguist and spoke a number of African languages, and this, coupled with his magnificent physical strength and power of endurance, 
charm of manner and sympathy, gained for him the respect and admiration of his African friends.

Essentially he was a man of independent thought and idealistic in his outlook; consequently he was not always practical in his own life, nor could he easily tolerate what he considered to be less enlightened views or opinions. In latter years he evinced an interest in and admiration for Islam, and embracing that faith he was buried as a Moslem. No one who met and knew him will easily forget his hospitality, good comradeship, his brilliant power of expression and the vivid descriptions of his wide and varied experiences in Africa and elsewhere; and his friends will be glad that he died suddenly, as he would have wished to die, and was spared a lingering illness.

E. B. HADDON.

WE regret to announce the following deaths :

Prof. H. Bateman, F.R.S., professor of mathematics, physics and aeronautics, California Institute of Technology, since 1917, aged sixty-two.

Dr. F. Bullock, secretary and registrar of the Royal College of Veterinary Surgeons, on February 14, aged sixty-six.

Major S. S. Flower, O.B.E., formerly director of the Zoological Gardens, Giza, on February 3, aged seventy-four.

\section{NEWS and VIEWS}

\section{Losses among Polish Zoologists during the War}

DR. T. JACZEWSKI, formerly acting director of the Polish Museum of Zoology, Warsaw, now attached to the Polish Repatriation Mission, B.A.O.R., has been able to compile the following data concerning the fate of Polish zoologists during the Second World War. The total death-roll amounted to fifty-four persons, that is, more than 25 per cent of the number of zoologists working in Poland in pre-war times. Of these fifty-four people, twenty-five died a natural death, although in most cases certainly a premature one, caused by hardships and privations under the German occupation; thirteen were killed in action, four were executed by the Germans, eight died in German concentration camps, and four are reported missing since 1939 or a later date. Eighteen were university professors, seven belonged to junior university personnel, ten to the staff of museums, biological stations, etc., six to the staff of economic zoological institutions, and thirteen were private workers. Among more prominent names may be mentioned : Prof. K. Bia aszewicz (University of Warsaw, physiology, died 1943), Prof. T. Garbowski (University of Cracow, animal psychology, died 1940 in con. centration camp, Oranienburg), Prof. E. Godlewski, jun. (University of Cracow, embryology, died 1944), Prof. S. Kopec̀ (University of Warsaw, general biology, executed 1941), Dr. Z. Koz̀miǹski (hydro. biology, killed in action 1939), Prof. R. Kuntze (Warsaw School of Agriculture, economic zoology, executed 1944), Dr. S. Minkiewicz (economic entomology, died 1944), Prof. W. Roszkowski (University of Warsaw, general and systematic zoology, executed 1944), Prof. M. Siedlecki (University of Cracow, general zoology, died 1940 in concentration camp, Oranienburg), Dr. J. Wiszniewski (hydrobiology, killed in action 1944). It is feared that the above data are still not quite complete, as the fate of several persons who left the country in 1939 or later, or were forcibly displaced by the Germans, is not yet certain.

\section{Acta Pharmacologica et Toxicologica}

Drscoveries of the last few decades have turned the minds of the medical world from preoccupation with diagnosis to the study of therapeutics and have greatly increased the importance of pharmacology. The Germans were the first to realize the possibilities of this subject, and at the end of the last century they led the world in the introduction of new remedies, but they had been overtaken by other countries before 1939. The output of papers on the action of new drugs is increasing rapidly but these papers tend to be scattered widely in all sorts of journals. There are not enough pharmacological journals, and there will be a widespread welcome for the Acta pharmacologica et toxicologica, the first numbers of which appeared in 1945. The new journal is published under the regis of the Pharmacological Society of Copenhagen. It is edited by Prof. K. O. Møller, with the collaboration of pharmacologists in Denmark, Sweden and Finland. Papers may be written in English, French or German, but all those in the first two parts are in English. The journal is attractively produced, and the editors are to be congratulated on the care which they have devoted to practically all the small points which make a journal convenient to use. The only obvious criticism is that the pages were uncut. It is hoped that this small fault can be remedied.

The first parts of the new journal contain a number of interesting papers on hormones and vitamins, and on drugs which antagonize these natural substances, on the precursor of acetylcholine, on the normal occurrence of piperidine in the urine and its pharma. cological properties, on biological standardization, on sulphonamides, and on the fate in the body of cyanides, alcohol, procaine and penicillin. This brief list gives some idea of the range and interest of the subjects covered. All good medical libraries will have to subscribe to this new journal. The price of each volume is 35 Danish kroner, post paid; the publisher is Einer Munksgaard, Nörregade 6, Copenhagen, Denimark.

\section{Universities Federation for Animal Welfare : Oxford Branch}

The inaugural meeting of the Oxford branch of the Universities Federation of Animal Welfare was held on February 22. Dr. Edward Hindle, president of the Federation, gave an address in which he stressed the fact that the humane treatment of animals is not simply a national question, but also an international one, and therefore most appropriate for a university body. Cruelty, he said, is not usually deliberate, but generally the result of ignorance and carelessness, and one of the main objects of the Federation is to try to spread information which would lead to a better state of affairs. A handbook on the care of laboratory animals, dealing with the health, feeding, 